
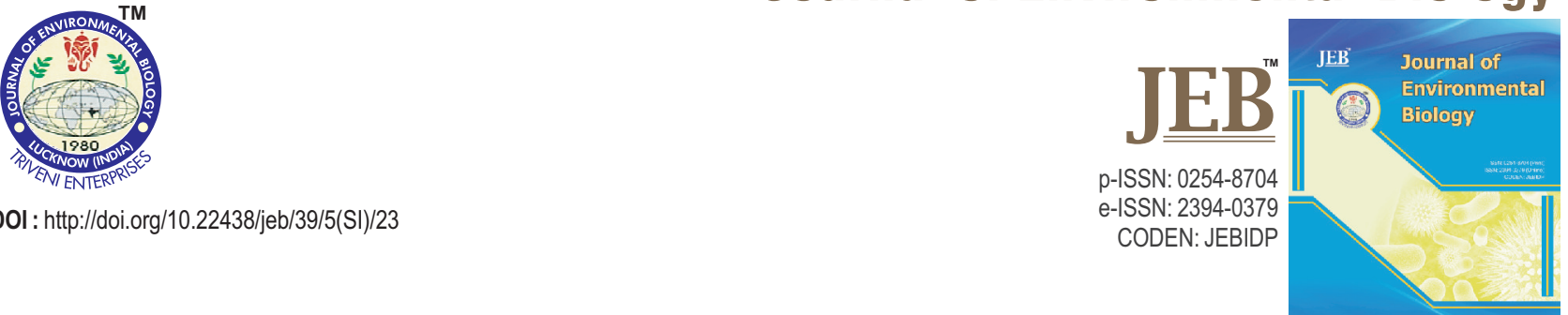

\title{
Fish diversity of an agriculturally influenced river in Bangladesh: Current profile, threats and management perspectives
}

\section{Authors Info}

Md. N. Siddiqye', M.B. Hossain ${ }^{1,2 * *}$, S.M.N Amin ${ }^{3}$ and Md. A. Ullah

'Department of Fisheries and Marine Science, Noakhali Science and Technology University, Noakhali, 3814, Bangladesh

${ }^{2}$ Research Cell, Noakhali Science and Technology University, Noakhali, 3814, Bangladesh

${ }^{3}$ Department of Aquaculture, Faculty of Agriculture, Universiti Putra Malaysia, 43400, Serdang, Selangor, Malaysia

*Corresponding Author Email : mbhnstu@gmail.com

\section{Key words}

Anthropogenic factors

Ecosystem

Endangered species

Fish conservation

Fish diversity

\section{Publication Info}

Paper received : 09.07.2017

Revised received : 07.10.2017

Re-revised received : 25.11.2017

Accepted : 28.12.2017

\begin{abstract}
Aim : Local and global stressors such as agricultural activities, climate change, habitat loss, eutrophication and pollution are the major causes of declining fish diversity. Therefore, for the management of fisheries and ecosystems, it is important to know the fish diversity of Little Feni River. The study was performed to know the diversity status of fishes in Little Feni River, Bangladesh during April - December, 2015.
\end{abstract}

Methodology : Fishes and their related data were collected from the Little Feni River of fish landing centers, fish markets, interviewing fishermen and arotdar (or known as commission agent).

Results : From this study, 47 species under 24 families were recorded in which $31(66 \%)$ species were from freshwater and the remaining $16(34 \%)$ species were from marine sources. Of the collected fishes, 26 species were categorized as not threatened (NT), 9 vulnerable (VU), 4 critically endangered (CR), 4 endangered (EN) and the remaining 9 could not be classified under the said list due to data deficient (DD). The results indicated the alarming decline of fish diversity in the investigated area in general and/or perhaps in the country as whole.

Interpretation : Long-term investigation, appropriate evaluation and proper documentation are urgently needed so that the public, investigators and policy makers would be able to know about the current status of fish diversity, and can take initiatives for proper conservation management practices towards the gradual decline of wild fish abundance in Little Feni River.

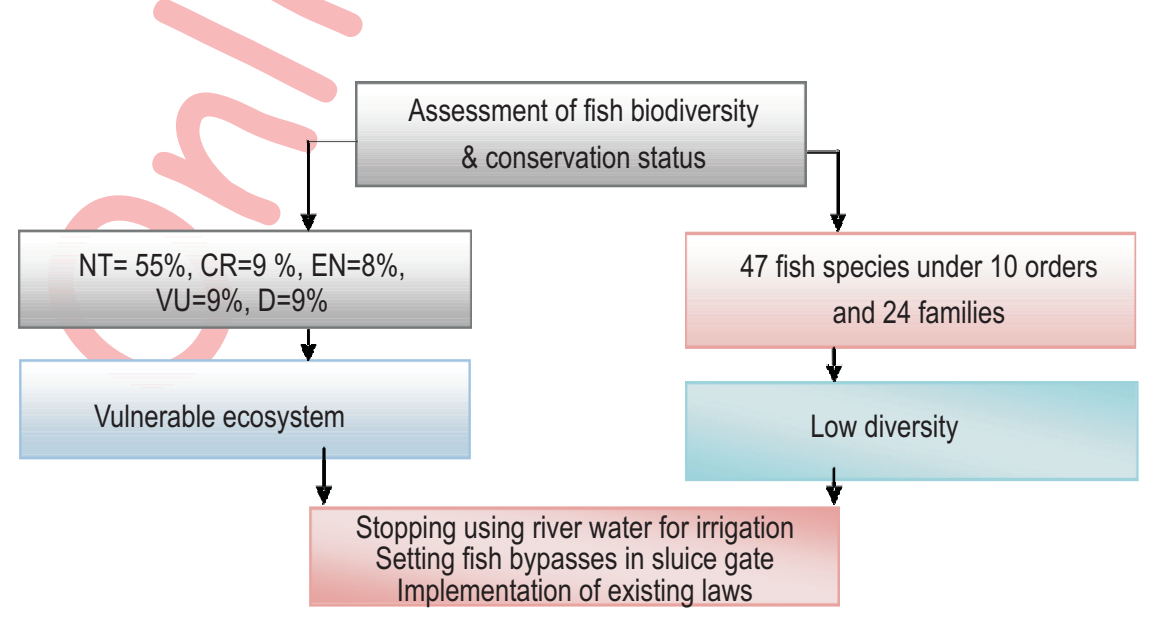




\section{Introduction}

Inland water fishery plays a major role in the animal protein supply of Bangladesh (Kibria and Ahmed, 2005; Hossain et al., 2006). In terms of overall production, Bangladesh is ranked fifth in inland fish production in the international fish market. In the country, there are 260 local fresh water fish species available (Rahman, 2005). These number vary on the basis of ecological characters of aquatic habitats (Rahman, 2005). Among the fish species, 54 species have been listed as threatened by International Union for Conservation of Nature (IUCN) from Bangladesh (DoF, 2005). Recent reports reveal that approximately 20 indigenous species have become extinct over the last 10 years due to various anthropogenic stresses including usage of varieties of nets for catching, insecticides and chemical fertilizers, as well as habitat depletion (DoF, 2012). If proper management steps are not taken and the scenario continues, nearly $70 \%$ of the local fish population may decline within short time which may cause severe extinction (DoF, 2012). Currently, reduction in the abundance of fish species from the inland waters of Bangladesh is a burning issue(Galib et al., 2009). Several studies on fish biodiversity have been reported throughout the world including the studies of Hasan (2007), Shinde et al. (2009), Emmanuel et al. (2010), Hossain et al. (2015), Khan (2011), Meye and Ikomi (2012) and Nyanti et al. (2012). Nowadays, fish biodiversity and management of associated habitats is a great challenge (Dudgeon, 2006). In addition, the conservation of aquatic biodiversity has gained great ecological importance over recent years (Hossain, 2012). However, the investigations are limited to assess the present status of fish diversity in Bangladesh. More importantly, no complete study has been conducted to reveal the status and causes of declining fish diversity in many parts of the country and Little Feni River is one of them. Hence, in this study an attempt was made to assess the status of fish diversity in Little Feni River , Bangladesh.

\section{Materials and Methods}

Data collection : Fish samples were collected during April 2015 December 2015 from Little Feni River adjacent fish landing centers and fish markets (Fig. 1). Data were collected by preparing a questionnaire interview, focus group discussion and cross check from the local people. Local names, distribution, availability of the species were also collected from the study sites. Secondary data were gathered from various published and unpublished relevant documents of various sources. Journal articles, conference proceedings and published books on the fish fauna of Bangladesh were also consulted to compile the previous data of abundance and availability for assessing the diversity status of the fish population from Little Feni River.

Design and test of questionnaire : A set of interview schedule was designed for data collection. Both closed and open form of questions were included in the questionnaire. Here, closed- ended questions could be answered by a simple "yes" or "no," and open-ended questions were those that required more thought and more than a simple one-word answer. Thus, final questionnaire was developed in logical sequence so that the fishermen could answer chronologically.

Collection of fish species and identification : Fish species were collected from the study area and preserved in a plastic container containing $10 \%$ formalin. The collected individuals were transported to the laboratory and for species identification, based on their morphometric and meristic characters following the methodology of Bhuiyan (1964), Rahman (2005), Talwar and Jhingran (1991) and Nelson (2016).

Data processing and analysis : The collected data were checked and summarized carefully before tabulation. After that, all the collected information was accumulated and analyzed in Excel program (ver. 2013). Finally, the data was presented in textual, tabular and graphical forms to understand the present fish population status of Little Feni River.

\section{Results and Discussion}

A total of 47 fish species under 24 families were collected from the study area (Table 1). The percentage analysis of the fish species showed the highest occurrence belonged to the following orders as follows: Perciformes (38\%), Siluriformes (26\%), Clupiformis (11\%), Decapoda (11\%) and others (2-4\%) (Fig. 2a). The family based percentage analysis of the fish species demonstrated the highest occurrence belonged to the family Bagridae (13\%), followed by Palaemonidea, Schilibeidae and Channidae (9\%), Engraulidae and Gobiidae (6\%) and others (24\%) (Fig. 2b). Based on conservation status, the recorded species were categorized under five statuses: not threatened (NT $=55 \%$ ), critically endangered ( $C R=9 \%)$, endangered $(E N=8 \%)$, vulnerable (VU $=9 \%$ ) and data deficient ( $D D=9 \%$ ) (Fig. 2C). The inland water fish status was much higher before twentieth century. Doha (1973) reported 106 species from Mymensingh and Tangail district; Islam and Hossain (1983) recorded 110 species from the river Padma; Hasan (2007) reported 33 species from Chitra and Fatki rivers; Zafar et al. (2007) reported 75 species from Pagla river; Bhuiyan et al. (2008) reported 73 species from Padma river near Rajshahi; Moumita et al. (2011) reported 59 species from Bangali river, Bogra and Ullah et al. (2016) mentioned 63 species from both freshwater and marine water bodies of selected mid coastal region of Bangladesh. So based on the available information, the current status of the fish population has been reduced, especially after twentieth century.

Also the results of this study clearly demonstrated the declining trends of fish diversity in Bangladesh. During this study it was observed that the anthropogenic causes such as, use of agrochemicals (pesticides and fertilizers) were the dominant declining causes of fish species in the investigated area. It was 


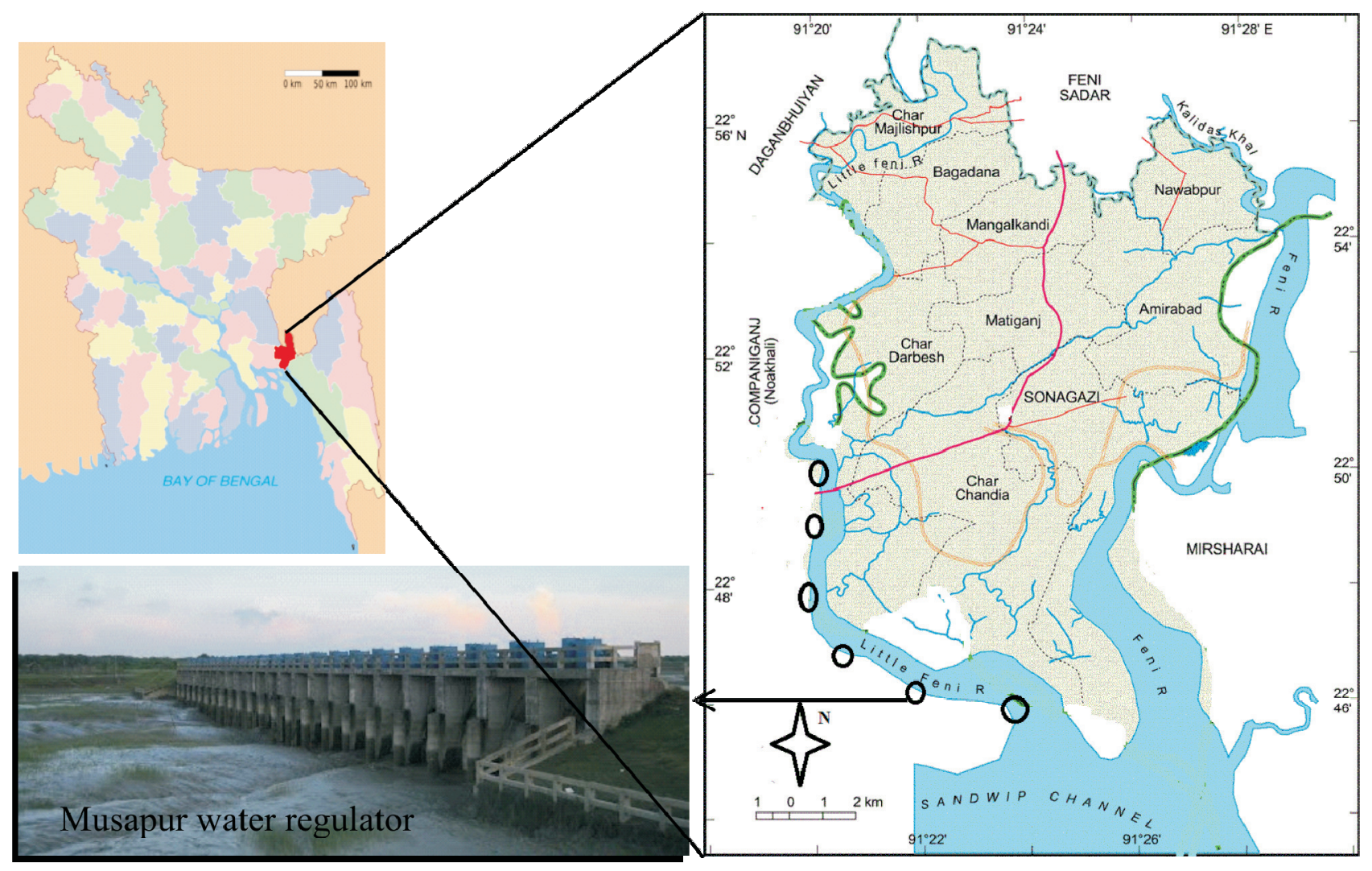

Fig. 1: Map showing the study area, Little Feni River. Photo (left-hand corner) shows the water control structure constructed across the river to facilitate agricultural activities during dry season

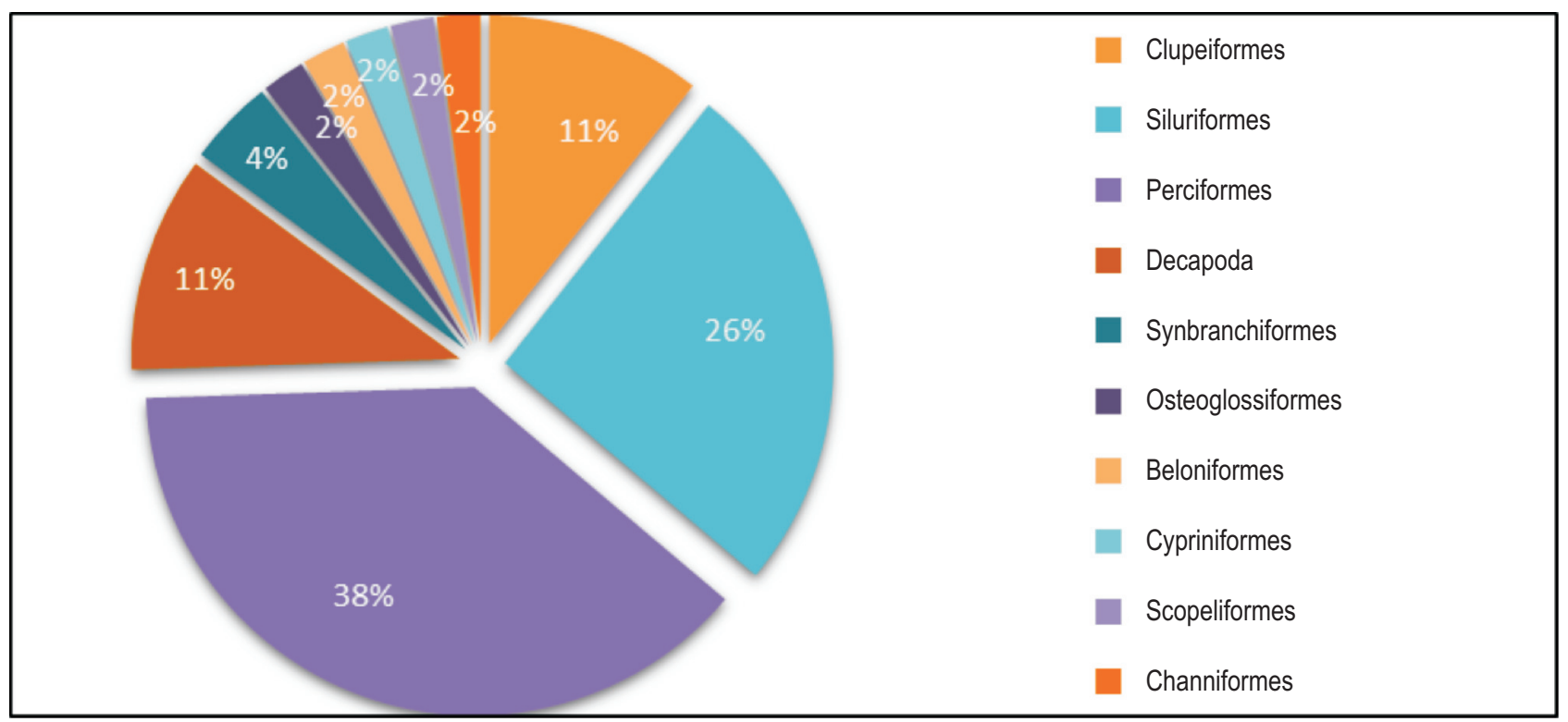

Fig. 2a: Percentage of fish species composition (Order level) in the Little Feni River 
observed that dam constructed across the river was impeding the water flow, and ultimately affecting the whole ecosystem of the Little Feni River. In addition, excess use of river water for irrigation, over exploitation, degradation of spawning grounds, catching of brood fish and fingerlings etc., are affecting the survival and existence of the fish fauna. The results of the present study were similar to the findings of Department of Fisheries (DoF, 2012), which reports that already 16 species of fishes are extinct from the Baral River due to the above mentioned reasons.
Toufique et. al. (1997) also reported similar declining causes of fish diversity of inland water bodies and recommended measure to enhance the survival of fish population. IUCN reported that 56 freshwater fishes (out of 260 species) are critically endangered and 50 species of fishes have become rare which were abundant in Bangladesh in last few decades (Hilton-Taylor and Craig, 2000).

Conservation and management perspective : Fishes, in

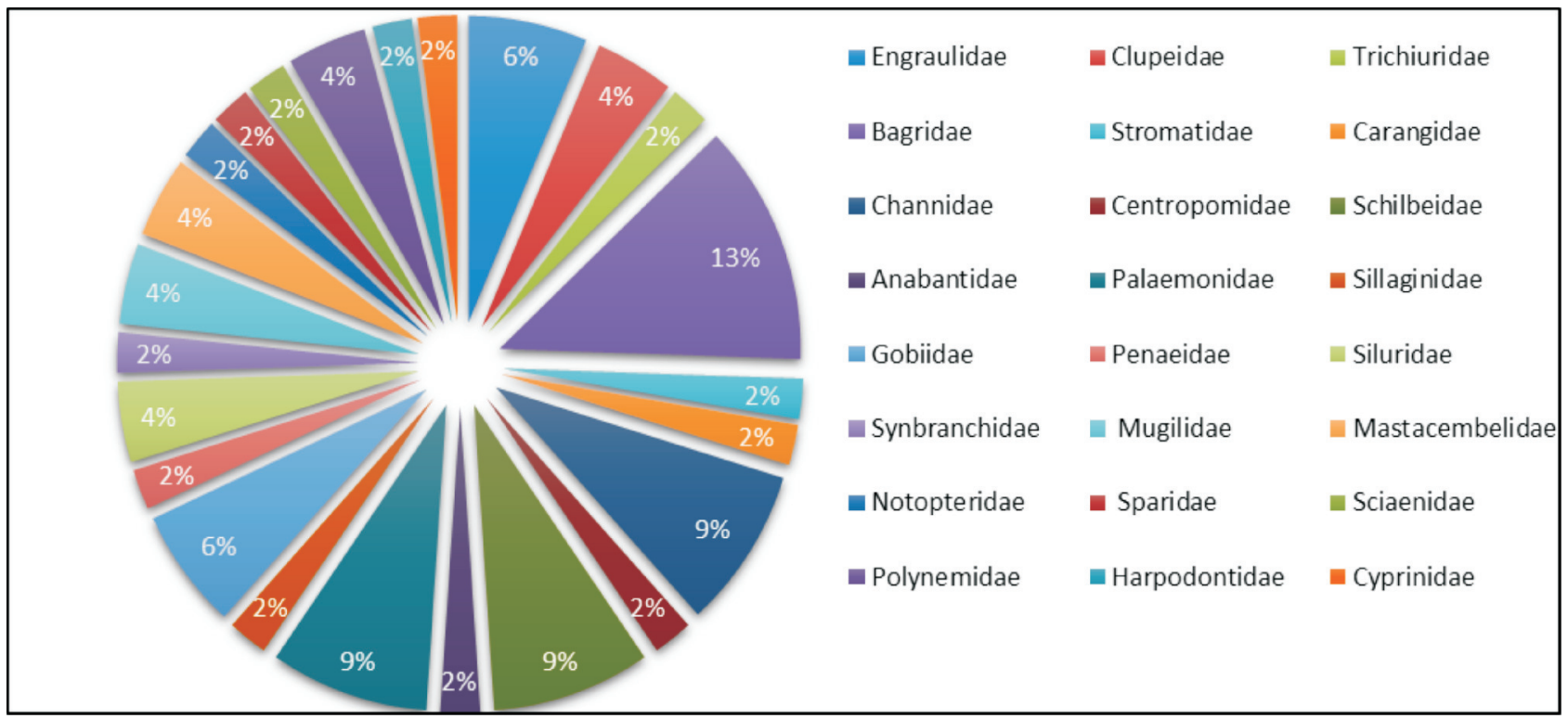

Fig. 2b: Percentage of fish species composition (Family level) in the study area

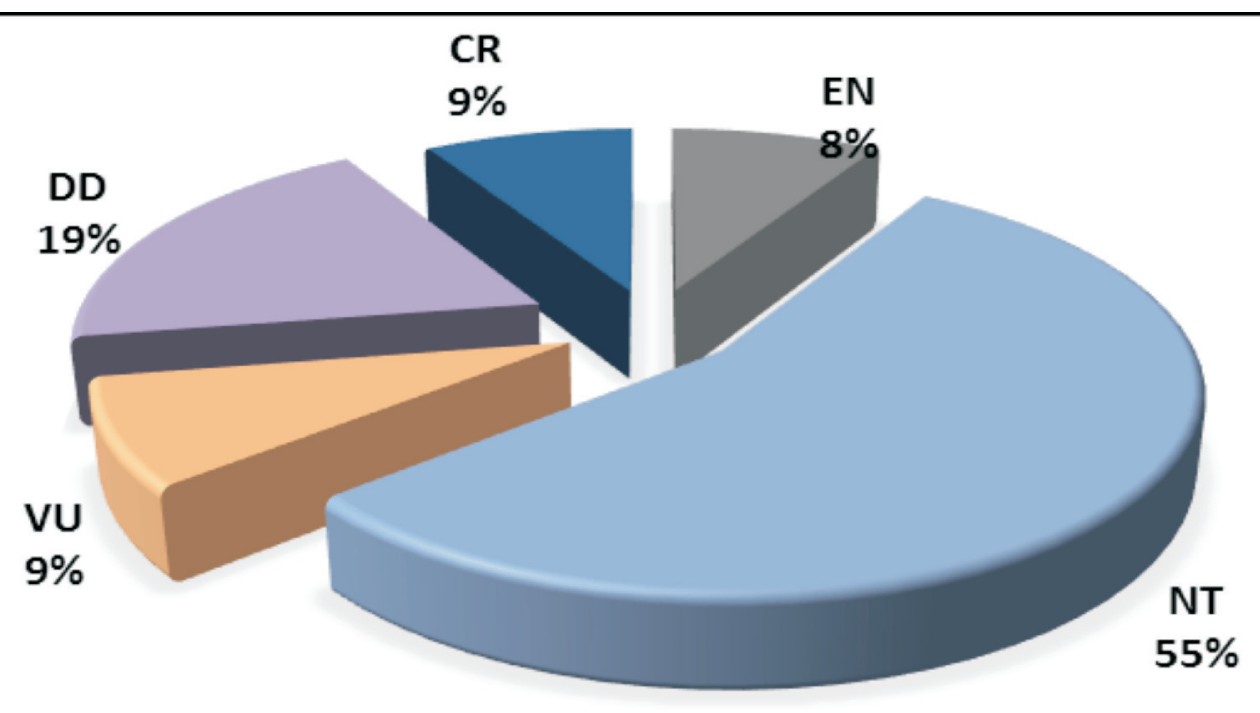

Fig. 2c: Conservation status of the fish species in the Little Feni River (classification based on IUCN National Categories, 2000) 
Table 1: Fish diversity in the Little Feni River with their conservation status

\begin{tabular}{|c|c|c|c|c|c|}
\hline Order & Family & Species & English name & Local name & Status $^{*}$ \\
\hline \multirow[t]{5}{*}{ Clupeiformes } & Engraulidae & Setipinna phasa & Gangetic Hairfin Anchovy & Phasa & NT \\
\hline & Clupeidae & Tenualosa ilisha & River Shad & Ilish & NT \\
\hline & Clupeidae & Gudusia chapra & Indian River Shad & Chapila & NT \\
\hline & Engrauliidae & Coilia dussumieri & Gold spotted Grenadier Anchovy & Olua & NT \\
\hline & Engraulidae & Setipinna taty & Scaly Hairfin Anchovy & Teli Phasa & NT \\
\hline \multirow[t]{12}{*}{ Siluriformes } & Bagridae & Batasio batasio & Tista Batasio & Batasi & EN \\
\hline & Siluridae & Wallago attu & Freshwater shark & Boal & NT \\
\hline & Schilbeidae & Eutropiichthys vacha & Batchwa Bacha & Bacha & $\mathrm{CR}$ \\
\hline & Bagridae & Mystus tengara & Stripped Dwarf Catfish & Bajari Tengra & NT \\
\hline & Bagridae & Rita rita & Rita & Rita & $\mathrm{CR}$ \\
\hline & Bagridae & Sperata aor & Long whiskered catfish & Ayer & VU \\
\hline & Siluridae & Ompok pabda & Pabda Catfish & Madhu Pabda & EN \\
\hline & Schilbeidae & Eutropiichthys murius & Murius Bacha & Muri Bacha & $\mathrm{DD}$ \\
\hline & Bagridae & Hemibagrus menoda & Menoda catfish & Gang Tengra & NT \\
\hline & Bagridae & Mystus gulio & Gulio catfish & Nuna Tengra & NT \\
\hline & Schilbeidae & Clupisoma garua & Garua Bacha & Gagra & $\mathrm{CR}$ \\
\hline & Schilbeidae & Ailia coila & Gangetic Ailia & Kajuli & NT \\
\hline \multirow[t]{18}{*}{ Perciformes } & Sparidae & Acanthopagrus latus & Yellow Seabream & Datina & $\mathrm{DD}$ \\
\hline & Sciaenidae & Otolithoides pama & Pama & Poa & NT \\
\hline & Mugilidae & Liza parsia & Goldspot Mullet & Khalla Bata & NT \\
\hline & Mugilidae & Rhinomugil corsula & Corsula Mullet & Bata & NT \\
\hline & Gobiidae & Apocryptes bato & Goby & Chewa Bele & NT \\
\hline & Gobiidae & Glossogobius giuris & Tank Goby & Bele/Baila & NT \\
\hline & Trichiuridae & Rastrelliger kanagurata & Trichiuridae & Champa & $\mathrm{DD}$ \\
\hline & Stromatidae & Scomberomorus guttatus & Spanish Mackerel & Maitta & NT \\
\hline & Polynemidae & Polynemus paradiseus & Paradise threadfin & Riksha & $\mathrm{CR}$ \\
\hline & Carangidae & Decapterus russelli & Indian shad & Surma & NT \\
\hline & Channidae & Channa marulius & Great snakehead & Gozar & EN \\
\hline & Channidae & Channa punctata & Spotted snakehead & Taki & NT \\
\hline & Channidae & Channa striata & Snakehead murrel & Shol & NT \\
\hline & Anabantidae & Anabus testudineus & Climbingperch & Koi & NT \\
\hline & Centropomidae & Lates calcarifer & Sea Bass & Koral & NT \\
\hline & Sillaginidae & Sillaginopsis panijus & Gangetic Sillago & Tular Dandi & NT \\
\hline & Polynemidae & Polynemus paradiseus & Paradise Threadfin & Taposi & NT \\
\hline & Gobiidae & Parapocryptes batoides & Goby & Chiring & NT \\
\hline \multirow[t]{5}{*}{ Decapoda } & Palaemonidae & Macrobrachium mirabilis & & Lotia icha & $\mathrm{DD}$ \\
\hline & Penaeidae & Penaeus monodon & Tiger Shrimp & Bagda icha & $\mathrm{DD}$ \\
\hline & Palaemonidae & Macrobrachium dolichodactylus & & Goda icha & $\mathrm{DD}$ \\
\hline & Palaemonidae & Macrobrachium rosenbergii & Freshwater Prawn & Golda icha & $\mathrm{DD}$ \\
\hline & Palaemonidae & Macrobrachium villosimanus & Freshwater Prawn & kokori icha & $\mathrm{DD}$ \\
\hline \multirow[t]{2}{*}{ Synbranchiformes } & Mastacembelidae & Mastacembelus armatus & Zig-zag eel & Baim & EN \\
\hline & Mastacembelidae & Macrognathus aculeatus & Lesser spiny eel & Tara baim & VU \\
\hline Osteoglossiformes & Notopteridae & Notopterus notopterus & Bronze featherback & Foli/Hoilla & VU \\
\hline Beloniformes & Belonidae & Xenentodon cancila & Freshwater garfish & Kaikya & NT \\
\hline Cypriniformes & Cyprinidae & Amblypharyngodon mola & Molacarplet & Mola & NT \\
\hline Scopeliformes & Harpodontidae & Harpodon nehereus & Bombay duck & Loitta & $\mathrm{DD}$ \\
\hline Channiformes & Channidae & Channa orientalis & Walking Snakehead & Gachua & VU \\
\hline
\end{tabular}

*Note : CR: Critically endangered; EN: Endangered; VU: Vulnerable; NT: Not threatened \& DD: Data deficient. Source: Red Book, IUCN, (2000)

Bangladesh where undernourishment remains a major development challenge, is an irreplaceable animal-source protein in the diet of millions. Fisheries sector contributes $60 \%$ of the animal protein to daily diet, $5.25 \%$ to GDP, and $6 \%$ to the export earnings of Bangladesh (Ullah et al., 2016). Being a tropical country Bangladesh is blessed with more than 200 rivers and 20 estuaries with high fisheries biodiversity. However, there is an increasing concern that a large number of fish fauna in the 
Table 2: Available fishes (Marine water) in the study areas during survey period

\begin{tabular}{lll}
\hline Local name & English name & Scientific name \\
\hline Phasa & Gangetic Hairfin Anchovy & Setipinna phasa \\
Tular Dandi & Gangetic Sillago & Sillaginopsis panijus \\
Chapila & Indian River Shad & Gudusia chapra \\
Ilish & River Shad & Tenualosa ilisha \\
Poa & Coiter Crocker & Otolithodes pama \\
Koral & Sea Bass & Lates calcarifer \\
Riksha & Paradise threadfin & Polynemus paradiseus \\
Gagra & Garua Bacha & Clupisoma garua \\
Bata & Corsula Mullet & Rhinomugil corsula \\
Chiring & Goby & Parapocryptes batoides \\
Muri vacha & Murius vacha & Eutropiichthys murius \\
Loitta & Bombay duck & Harpodon nehereus \\
Surma & Indian shad & Decapterus russelli \\
Teli Phasa & Scaly Hairfin Anchovy & Setipinna taty \\
Gang Tengra & Menoda catfish & Hemibagrus menoda \\
Olua & Gold spotted Grenadier & Coilia dussumieri \\
\hline
\end{tabular}

Table 3: Available fishes (Fresh water) in the study areas during survey period

\begin{tabular}{|c|c|c|}
\hline Local name & English name & Scientific name \\
\hline Batasi & Tista Batasio & Batasio batasio \\
\hline Boal & Freshwater shark & Wallago attu \\
\hline Bacha & Batchwa Bacha & Eutropiichthys vacha \\
\hline Bajari Tengra & Stripped Dwarf Catfish & Mystus tengara \\
\hline Rita & Rita & Rita rita \\
\hline Ayer & Long whiskered catfish & Sperata aor \\
\hline Madhu Pabda & Pabda Catfish & Ompok pabda \\
\hline Nuna Tengra & Gulio catfish & Mystus gulio \\
\hline Kajuli & Gangetic Ailia & Ailia coila \\
\hline Datina & Yellow Seabream & Acanthopagrus latus \\
\hline Khalla Bata & Goldspot Mullet & Liza parsia \\
\hline Chewa Bele & Goby & Apocryptes bato \\
\hline Bele/Baila & Tank Goby & Glossogobius giuris \\
\hline Champa & Trichiuridae & Rastrelliger kanagurata \\
\hline Maitta & Spanish Mackerel & Scomberomorus guttatus \\
\hline Gozar & Great snakehead & Channa marulius \\
\hline Taki & Spotted snakehead & Channa punctata \\
\hline Shol & Snakehead murrel & Channa striata \\
\hline Koi & Climbingperch & Anabus testudineus \\
\hline Taposi & Paradise Threadfin & Polynemus paradiseus \\
\hline Lotia icha & & Macrobrachium mirabilis \\
\hline Bagda icha & Tiger Shrimp & Penaeus monodon \\
\hline Goda icha & & Macrobrachium dolichodactylus \\
\hline Golda icha & Freshwater Prawn & Macrobrachium rosenbergii \\
\hline Kokori icha & & Macrobrachium villosimanus \\
\hline Baim & Zig-zag eel & Mastacembelus armatus \\
\hline Tara baim & Lesser spiny eel & Macrognathus aculeatus \\
\hline Foli/Hoilla & Bronze featherback & Notopterus notopterus \\
\hline Mola & Molacarplet & Amblypharyngodon mola \\
\hline Gachua & WalkingSnakehead & Channa orientalis \\
\hline Kaikya & Freshwater garfish & Xenentodon cancila \\
\hline
\end{tabular}


coastal region of Bangladesh are still out of assessment due to insufficient research. Over the last decade, fish biodiversity of riverine and estuarine ecosystems across Bangladesh have reduced considerably due to anthropogenic affects, tourism, pollution, natural hazards and climate change that resulted in destruction of migratory routes, altered habitats and deteriorated water quality (Hossain et al., 2015; IUCN Bangladesh, 2013). Therefore, IUCN, categorized many species as endangered in Bangladesh (IUCN Bangladesh, 2013). Based on the observation and findings of present investigation, the following conservation measures and management strategies are suggested to conserve the biodiversity of fish species in this area:

- A long term thorough study of biodiversity, distribution and life history of fishes to inform management agencies to help them in decision making and improve the management policies and strategies.

- $\quad$ Raising awareness about the importance of fish and their habitat conservation through proper channel (or communication), cooperation and education.

- Introduction of fish bypasses in water control structures to ease fish migration.

- Reducing or stopping use of river water for irrigation, especially when water level and flow is low.

- $\quad$ Banning of fishing during spawning season, and use of illegal and destructive fishing gears to reduce overfishing.

- Stopping indiscriminate catching of fry and fingerlings.

- Declaration of fish sanctuary in the major depressions of the river.

- Increasing more wild fish in aquaculture systems.

- Enhancing fisheries resources through restocking.

- Effective implementation of existing fisheries regulations e.g., National Fisheries Policy (1998), National Fisheries Strategy (2006), The Protection and Conservation of Fish Rules (1985) etc.

- Therefore, it is an urgent need to facilitate alternative income-generating activities for rural fishermen to reduce dependency on fishing.

\section{Acknowledgments}

We would like to thank the Department of Fisheries and Marine Science, Noakhali Science and Technology University for providing all sorts of laboratory facilities during the study period. We are also thankful to the fishermen and other relevant stakeholders of the study area for their help in collecting samples and providing important information to carry out the research work.

\section{References}

Bhuiyan, A.L.: Fishes of Dacca (No. 13). Asiatic Society of Pakistan (1964).

Bhuiyan, S.S., M.A.R. Joadder and A.S. Bhuiyan : Occurrence of fishes and non-fin fishes of the river Padma near Rajshahi, Bangladesh. Univ. J. Zool., 27, 99-100 (2008).

DoF (Department of Fisheries): Jatiya Matshya Pakkha Shankalan 2005. Department of Fisheries, Bangladesh, pp. 133-134 [in Bengali]. (2005).

DoF : Department of Fisheries, Dhaka, Bangladesh (2012).

Doha, S.: Fishes of the districts of Mymensingh and Tangail. Bangladesh J. Zool, 1, 1-10 (1973).

Dudgeon, D., A.H. Arthington, M.O. Gessner, Z.I. Kawabata, D.J. Knowler, C. Leveque, R.J. Naiman, A.H. Prieur-Richard, D. Soto, M.L.J. Stiassny and C.A. Sullivan: Freshwater biodiversity: Importance, threats, status and conservation challenges. Biol. Rev., 81, 163-182(2006).

Emmanuel, L.O. and O.O. Modupe : Fish diversity in three tributaries of river Ore, South West, Nigeria. World J. Fish. Mar. Sci., 2, 524531(2010).

Galib, S.M., M.A. Samad A.B.M. Mohsin F.A. Flowra and M.T. Alam : Present status of fishes in the Chalan Beel- the largest beel (Wetland) of Bangladesh. Int. J. Ani. Fish. Sci., 2, 214-218 (2009).

Hasan, M.: Fisheries problems and potential of the Chitra and Fatki rivers. Bangladesh J. Fish., 30, 105-111 (2007).

Hilton-Taylor, Craig. IUCN Red list of threatened species. IUCN, 2000.

Hossain, M. Y., Z. F. Ahmed, P. M. Leunda, A. K. M. Roksanul Islam, S. Jasmine, J. Oscoz, R. Miranda and J. Ohtomi: Length-weight and length-length relationships of some small indigenous fish species from the Mathabhanga River, South-western Bangladesh. J. Appl. Ichthyol., 22, 301-303 (2006).

Hossain, M. Y., M. A. Hossain, Z. F. Ahmed, R. Islam, M. A. Hossen M. M. Rahman and J. Ohtomi : Threatened fishes of the world: Eutropiichthys vacha (Hamilton, 1822) (Siluriformes: Schilbeidae). Croat. J. Fish., 73, $80-82$ (2015).

Hossain, M.Y., M.M. Rahman, M.A.S. Jewel, Z.F. Ahmed, F. Ahamed, B. Fulanda and J. Ohtomi : Conditions and form-factor of the five threatened fishes from the Jamuna (Brahmaputra River Distributary) River, Northern Bangladesh. Sains Malaysiana, 41, 671-678 (2012).

Islam, M.S. and M.A. Hossain : An account of the fishes of the Padma river near Rajshahi. Raj. Fish. Bull., 1, 1-31 (1983).

IUCN Bangladesh: Red book of threatened fishes of Bangladesh, IUCNThe world conservation union. pp. 12-116 (2013).

Khan, M.A. and Z. Hasan : A preliminary survey of fish fauna of Changhoz dam, Karak, K.P.K. Pakistan. World J. Fish. Mar. Sci., 3, 376-378 (2011).

Kibria, M. G. and K. K. U. Ahmed : Diversity of selective and nonselective fishing gear and their impact on inland fisheries in Bangladesh. NAGA, 28, 43-48 (2005).

Meye, J.A. and R.B. Ikomi,: Seasonal fish abundance and fishing gear efficiency in river Orogodo, Niger delta, Nigeria. World. J. Fish. Mar. Sci., 4, 191-200 (2012).

Moumita, D., M. A. Hussain M. M. Alam A. G. Mazlan and K. D. Simon : Impact of Sariakandi fish pass on fisheries diversity of Bangali river, Bogra, Bangladesh. AACL Bioflux, 4, 621-626 (2011). 
Nelson, J.S., T.C. Grande and M.V. Wilson : Fishes of the World. John Wiley \& Sons (2016)

Nyanti, L., T.Y. Ling and G. Jongkar,: Fish and crustacean communities and fish length weight relationship of Lutong River, Miri, Sarawak, Malaysia. World. J. Fish. Mar. Sci., 4, 102-110 (2012).

Rahman, A. K. A.: Freshwater fishes of Bangladesh ( $2^{\text {nd }}$ Eds.). The Zoological Society of Bangladesh, Dhaka, p. 394 (2005).

Shinde, S.E., T.S. Pathan, K.S. Raut, R.Y. Bhandare and D.I. Sonawane,: Fish biodiversity of Pravara River at Pravara Sangam district Ahmednagar, (M.S.) India. World. J. Zool., 4, 176-179 (2009).
Talwar, P.K. and A.G. Jhingran : Inland fishes of India and adjacent countries. Vol. 2, CRC Press (1991).

Toufique, K.A.: Some observations on power and property rights in the inland fisheries of Bangladesh. World Development, 25, 457-467 (1997).

Ullah, M.A., M.N. Uddin, M.S. Hossain, M.B. Hossain and M.A. Hossain : Fish diversity in three selected areas of mid-coastal region, Bangladesh. J. Fish. Aquat. Sci., 11, 174-185 (2016).

Zafar, M.S., S.M.N. Amin and M.J. Iqbal : Biodiversity of fisheries organisms in the Pagla river of Bangladesh. Bangladesh J. Fish, 30, 165-175(2007). 